\title{
Article \\ Sustainability of Wetlands in the Eyes of the New Generation of Environmental Engineering Students
}

\author{
Farshad Amiraslani
}

check for updates

Citation: Amiraslani, F.

Sustainability of Wetlands in the Eyes of the New Generation of Environmental Engineering Students. Conservation 2021, 1, 182-195.

https://doi.org/10.3390/

conservation 1030015

Academic Editor: Antoni Margalida

Received: 6 July 2021

Accepted: 20 July 2021

Published: 26 July 2021

Publisher's Note: MDPI stays neutral with regard to jurisdictional claims in published maps and institutional affiliations.

Copyright: (C) 2021 by the author. Licensee MDPI, Basel, Switzerland. This article is an open access article distributed under the terms and conditions of the Creative Commons Attribution (CC BY) license (https:// creativecommons.org/licenses/by/ $4.0 /)$.
School of Geography \& Environmental Sciences, Faculty of Life \& Health Sciences, Ulster University, Coleraine BT52 1SA, UK; f.amiraslani@ulster.ac.uk

\begin{abstract}
This research paper investigates the general understanding and skills of young third-year environmental engineering students concerning the criteria for monitoring wetlands. Students were asked to describe approaches, data, and final solutions to identify and/or eliminate wetland odor. Over half of the students $(55 \%)$ did not consider the "identification" strategy by which to determine the source of unexpected odors. The rest gave answers focused on "restoration" (24\%) and "prevention" (15\%) strategies, while $6 \%$ of the answers were unrelated. In fact, without knowing the causes and without thinking about the necessity/importance of visiting/surveying the site, students came up with a priori solutions. In their mind, the immediate cause of the odor could be a disturbed or unbalanced distribution/composition of ions, salts, or microbes in the water. Indeed, most data types $(71 \%)$ were those related to "water". As the final solution, $50 \%$ of responses considered "physical" followed by "legal and planning" solutions (32\%). Each factor, including "Chemical" and "Biological", constituted $9 \%$ of the answers. This research highlights engineering students" communication skills, critical thinking and problem-solving abilities by contemplating class activities that simulate real-world situations. The research presumes that these engineering student cohorts represent typical student communities worldwide. Such findings contribute to policymaking in the engineering education system on a larger scale.
\end{abstract}

Keywords: wetland; sustainability; undergraduate students

\section{Introduction}

Undoubtedly, in addition to following their standard academic syllabuses, environmental engineering students must acquire communication, collaboration, and negotiation skills. These so-called "twenty-first-century" skills [1] also include critical thinking, problem-solving, social skills, and more.

One of the best learning-training scenarios for university educational systems is that universities provide such students with the courage, impetus, and motivation for asking questions, searching for answers, designing experiments, performing laboratory experimentation, manipulating equipment, and conducting interactive debates and outdoor searches [2]. Such a system encourages students' imagination, self-confidence, analytical and numerical skills, and team working. These digitally savvy millennials spend much of their time on online chatting and gaming, so it is reasonable to encourage them to experience more real-life aspects. As a result, it is also recommended to encourage undergraduate students to learn the skills to use, manipulate and interpret large-scale datasets [2].

Nowadays, however, university students adversely encountered unilateral class discussions and visualized slide presentations in which they pretend to be perfect audiences and note-takers (personal communications with students). In this case, innovation and critical thinking are compromised by daunting clock-checking, sleeping and windowwatching (see, e.g., [3]). Such divided attention will reduce the long-term retention of the classroom lecture [4]. This situation incurs severe consequences, especially for engineering students, as they will be involved in large-scale, expensive, and human-based projects after graduation. 
On a personal level, many of these undergraduate students may end up in other academic disciplines for their postgraduate study or land in industries beyond their common professional career goals. Such cross-linkage is becoming more visible globally, as environmental science and engineering topics are becoming entangled with socio-economic and legal matters. Therefore, it is pivotal for these students to be engaged in more natural and tangible class activities and field works rather than vacuumed, isolated and unilateral lecture-based classes.

Generally, while to "enable students to become critical and active participants in society" ([5], p. 1285) is heralded as an educational approach, university engineering students may not be trained appropriately in such non-numerical social skills.

This research paper examined young Chinese environmental engineering students' understanding and skills in identifying and responding to a typical environmental concern. The research was set up based on a class activity presenting a scenario in which unpleasantly smelly conditions were portrayed for a presumptive wetland. Students were asked about approaches, data, and the final solutions to eliminate this odor, during the class activity. By propounding a tangible condition, the class activity simulated an actual situation that may occur at any time in the natural world.

The objectives of this research were two-fold. First, we strove to inquire about the general knowledge of the third-year engineering students on the sustainability issue. At this stage of the study, they are inexperienced professionally and have not yet been exposed to any significant outdoor activity. Second, we explored how undergraduate students would observe technical matters and link them with the social aspects. In a rare attempt, the research aimed at appreciating two unrelated and unattested aspects among engineering students. It indirectly sought to inquire about the level of technical skills and the social readiness of these engineering students.

The novelty of this research lies within the two main domains. Contrary to a plethora of research on Western environmental education systems, there is a dearth of such research exploring the Asian context. Little effort has been made to investigate environmental education in any non-Western context, although most of the diverse range of environmental challenges exist in Asian countries. A few such Asian contexts were found, e.g., [6]. Thus, this research focuses on the perception of Asian students studying environmental engineering at an Asian university. The second novelty is that this research employs a structured query language (SQL) for data analysis that allows us to establish relationships, accurately and quickly, among a large amount of data scattered in tables. Finally, although not as a novel but as a positive direction, this research uses the actual words chosen by the participants, rather than "fill in the blank" or "ticking the boxes" methods that comprise a predefined set of (multiple-choice) answers in questionnaires that may be biased toward the purposes of the research.

\section{Background}

\subsection{Conceptualization: The Necessity of Environmental Education}

The concept of literacy has been modified and broadened over time. Nowadays, diverse forms of literacy exist, from digital to environmental literacy or ocean literacy [7]. Environmental literacy refers to "the capacity to perceive and interpret the relative health of environmental systems and take appropriate action to maintain, restore, or improve the health of those systems" (Disinger and Roth, as cited by [8]). It is noted that people still have a limited understanding of marine-related phenomena and marine environmental protection [7]. Accordingly, there is a call for connecting contemporary young people with nature, to tackle the so-called "nature-deficit disorder" through facilitating environmental education [9], experiential learning within eco-attractions [10], or improving intergenerational learning about conservation [11]. Modern technical data processing systems are increasingly being used to monitor and observe environmental changes and to be entwined with social dimensions, under a new realm known as "citizen science" (see [12] for more details). In turn, this scientific-social consolidation is believed to be capable of 
broadening the effectiveness and power of these modern systems (e.g., satellite remote sensing) [12]. In particular, younger generations and teenagers must be equipped with the skills to tackle multifaceted global challenges (e.g., "knowledge on climate change" [13]; "multi-level governance of climate change" [14]; "ownership rights and environmental protection" [15]; "fossil fuels and climate justice" [16]). This fact is even more apparent for those younger generations and teenagers who intend to train and be involved professionally in an environment-related academic field.

Environmental science and the engineering discipline are greatly intertwined with challenging social and humanistic issues in the real world [17] and, thus, inherit much more complexity, ambiguity, and difficulty. Students must acquire various areas of knowledge and skills in a diverse range of primary and applied sciences to face global, regional, national and local uncertainties. Finally, within the context of environmental education, students' capacities must be augmented to enable them to collaborate and implement the appropriate policies and regulations to tackle the challenges [16].

As in other academic disciplines, the assessment of educational systems, philosophy, methods, and approaches in "environmental science and engineering" have increased over the past few years. From camera-recording to questionnaires, to the literature review, scholars have used tools to explore a diverse range of subjects, methodologies, and participants in the context of community-based or pre-university/university programs (Table 1).

Table 1. Selected research subjects and their associated methodologies in analyzing environmental education.

\begin{tabular}{|c|c|c|c|}
\hline Subject & Methodology & $\begin{array}{l}\text { Number of Participants (Age } \\
\text { Group) }\end{array}$ & Source \\
\hline Climate change awareness & $\begin{array}{l}\text { Online } \\
\text { questionnaire }\end{array}$ & 792 students (13 to 16 years) & [13] \\
\hline Nature and culture & In-depth interviews & 430 students (13 to 24 years) & {$[10]$} \\
\hline $\begin{array}{l}\text { Ownership rights and } \\
\text { environmental protection }\end{array}$ & Questionnaire & 1900 students (undergraduate) & [15] \\
\hline Jaguar conservation & $\begin{array}{l}\text { Questionnaire, } \\
\text { interview, open-ended questions }\end{array}$ & $\begin{array}{l}151 \text { students ( } 11 \text { to } 14 \text { years; mean age } \\
12.63 \text { ) and their fathers ( } 172 \text { adults; } \\
\text { mean age } 46.38)\end{array}$ & {$[11]$} \\
\hline $\begin{array}{l}\text { Fossil fuel and } \\
\text { climate justice }\end{array}$ & Interviews & $\begin{array}{l}21 \text { teachers (primarily grades } 7-12 \text { ), } \\
\text { three } \\
\text { out-of-classroom educational } \\
\text { employees, two administrators, as } \\
\text { well as three representatives from } \\
\text { organizations }\end{array}$ & [16] \\
\hline $\begin{array}{l}\text { Crafting materials and } \\
\text { sustainability }\end{array}$ & Camera recording & 15 students (Grades 3-9) & [18] \\
\hline Sustainable development & Focus group & 34 teacher instructors $(n / a)$ & {$[19]$} \\
\hline $\begin{array}{l}\text { Crosscutting } \\
\text { environmental education }\end{array}$ & Holding workshop & $\begin{array}{l}\text { (n/a) (Environmental education } \\
\text { experts and practitioners) }\end{array}$ & {$[1]$} \\
\hline $\begin{array}{l}\text { Environmental identity, } \\
\text { decision-making process, } \\
\text { and behavior }\end{array}$ & Three-part survey & 299 undergraduate students & {$[20]$} \\
\hline College students and nature & $\begin{array}{l}\text { Survey using } \\
\text { Qualtrics platform }\end{array}$ & 287 undergraduate students & [21] \\
\hline varied & Literature review & $\mathrm{n} / \mathrm{a}$ & {$[22-24]$} \\
\hline
\end{tabular}


In addition to the necessity of environmental education, many articles predominantly emphasize supplementary methods to involve learners in learning-by-doing, outdoor activities, field schools, etc. In fact, "issue-based, project-based, and investigation-focused programs in real-world nature settings" would achieve the desired outcomes for environmental educational programs [25]. For pre-university students (aged 13-14 years), the outdoor environment was found to encourage students to experience natural phenomena that are rooted in the real world [26]. There is also a reality that the world is changing fast, and "events in the 'real' world have done much to expose the giddy volatility of the new economics, ... political agenda, and the 'spin' and 'hype' ... " ([27], p. 433) and, on the other hand, "knowledge is embedded in larger structures of society and culture" ([28], p. 165). With no experience in seeing different places, students cannot empathize with change and development [29].

Therefore, the exposure of environmental engineering students to real-world situations is more achievable than exposure to a unilateral teaching method. Although the development of field-based classes for students is invaluable, conducting entire courses in the field is usually rare for logistical reasons [29]. If fieldwork is not feasible, lecturers in environmental engineering sciences can create an atmosphere in the class that stimulates students' thinking by exposing them to real-world situations.

\subsection{Wetlands as the Functional Ecosystems}

In this research, the core class inquiry evolved around a topical question on wetlands. Students were tested against their overall knowledge of monitoring, functionalities, and the sustainability issues surrounding wetlands. Therefore, before elaborating on data and methods in the next section, a brief introduction to a few examples of scientific terminology and concepts regarding wetlands, the global condition of wetlands and wetland odor are discussed here. It will help readers perceive the question's relevancy to the real world and track the student responses with their own responses.

According to a globally accepted definition, wetlands "include a wide variety of habitats such as marshes, peatlands, floodplains, rivers and lakes, and coastal areas such as salt marshes, mangroves, and seagrass beds, but also coral reefs and other marine areas no deeper than six meters at low tide, as well as human-made wetlands such as waste-water treatment ponds and reservoirs" [30]. By rendering a diverse range of ecosystem services, wetlands are regarded as one of the most significant habitats for achieving sustainable development goals [31].

Wetlands have been affected severely by both anthropogenic and natural factors; they have dried up or lost their functionalities over time. A $35 \%$ decline in natural wetland areas has been recorded globally between 1970 and 2015 [31]. Therefore, a wetland inventory has been proposed to monitor wetlands that include both technical and humanistic dimensions (Box 1).

Box 1. Wetland inventory.

The wetland inventory includes: (a) listing particular types of, or even all, wetlands in an area; (b) listing wetlands of local, national and/or international importance; (c) describing the occurrence and distribution of wetland taxa; (d) describing the occurrence of natural resources such as peat, fish or water; (e) establishing a baseline for measuring changes in the ecological character of wetlands; (f) assessing the extent and rate of wetland loss or degradation; (g) promoting awareness of the value of wetlands; (h) providing a tool for conservation planning and management; and (i) developing networks of experts and cooperation for wetland conservation and management (see [30], pp. 11-12).

This research asks about the reasons for and solutions regarding unpleasant wetland odor in an imaginary location. Odors are generally regarded as one of the natural physical characteristics of surface waters. The chemical compositions and variations of odors depend on their substrates and/or climatic conditions (e.g., temperature). However, unpleasant odors are obnoxious and are regarded as an "environmental nuisance" that affects the amenity and comfort of communities [32] and, in some cases, potential odors impact public 
health and wellbeing [33]. Odor intensity is "the perceived strength of an odor above its threshold", and is described by numerical scales as from "not perceptible (Level 0) ... to extremely strong (Level 6)" [34]. Five factors are suggested regarding odor complaints: the frequency of the odor occurrence, the intensity of the odor, duration of exposure to the odor, the offensiveness of the odor, and location of the odor (the New Zealand Ministry for the Environment, cited by [34]).

One reason for wetland odor in the natural environment is that sulfur gases generate a foul smell (rotten eggs) after being emitted. This emission process is affected by salinity, the wetting-drying regime, soil type and diurnal cycles [35]. However, other potential reasons for generating odors may exist that are not related directly to the water body of wetlands (e.g., the existence of animal wastes). Simpson and Newsome [36] reported the emission of odors from a wetland in Perth (Australia). They pointed to factors such as fertilizers and animal fecal runoff, and the number of nutrients entering the wetlands that are leaching from sanitary landfill sites and rotting organic material. These noxious odors are emitted whenever the levels of these materials exceed the capacity of the ecosystems natural filtration and sequestration processes [36]. Based on one year of meteorological data, however, separation distances between odor-emitting sources and residential areas can be measured as a means of protecting local people [33].

\section{Data and Methodology}

\subsection{Targeted Research Group}

Third-year bachelor's degree in Environmental Engineering students in a particular Chinese university were screened in this research. These students were taking the "Water Pollution Control" module during the winter semester in 2019. The module covered a broad range of inter-related topics, including biology, microbiology, organisms, diseases, and the physicochemical properties of aquatic environments. Halfway through the semester, all module attendees (33 young students) were asked to consider and answer questions required as part of the syllabus. The assignment examined in this paper was not part of the formal syllabus; instead, it was an informal class activity.

\subsection{Data Collection}

The research was conceived based on discourse analysis. A discourse is "a specific ensemble of ideas, concepts, and categorizations that are produced, reproduced and transformed in a particular set of practices and through which meaning is given to physical and social realities" (Hajer, cited by [12], p. 15). By considering this definition, this research has collated the ideas produced by students to test their knowledge about recognizing the realities they may face in real situations.

In this research, a question consisting of three parts was propounded to engineering students in the class (Box 2). Then, they were asked to answer these questions on answer sheets and were given $45 \mathrm{~min}$. Students were not allowed to use online sources to support their thoughts and ideas. In addition, they were not given any particular or subjective direction, neither through the answer format/template nor in writing/wording styles. These qualitative notes (answer sheets) were used for further steps in the research.

Box 2. The three-part question propounded to students.

In Zone A, local people ask for the reason/source of an unexpected odor in an adjacent wetland. It has been the case for the last few days, and the situation has got worse. As an expert, you have been asked to investigate.

1. What approaches do you suggest, to deal with this situation?

2. What type of data must be collected for further investigation?

3. What will be the final solutions for eliminating this odor in the long run? 
"Coding is the process whereby raw data are systematically transformed and aggregated into units which permit a precise description of relevant content characteristics" (Holsti, cited by [15]). Here, each answering sheet was assigned a code to ease referencing and to eliminate the probable subjectivity. At the core of the coding procedure is "a need to identify and correctly apply the wording from individual answers into conceptual categories ... that accurately reflect ... the participants' views" ([15], p. 7). This research extracted relevant words/statements based on each part of the question (Box 3). It must be noted that English was not the first language of these students, although all answers were given in English. Thus, extracted statements were refined and uniformed for a lexical reason, and then categorized under the corresponding column. In another attempt, uniform titles were defined for columns and rows in a spreadsheet file under which each piece of extracted data could be located. Accordingly, data were clustered in a database with a framed structure that will be clarified in detail for each question separately in the "Results" section. It must be noted that each code was considered as a separate, single "entity", but it could possess several "entries". Over 1300 entries were extracted, cross-checked, and used to compile a database covering separate sheets for each question at the end of the process.

Box 3. Typical student answers.

\begin{tabular}{|c|}
\hline $\begin{array}{l}\text { n the following four examples, the underlined statements were renamed to "site investigation } \\
\text { and were used as selected entries in the proposed database: } \\
\text { ite investigation is needed to deal with this situation (code 2) }\end{array}$ \\
\hline ........ do on-the-spot investigation .... .. \\
\hline
\end{tabular}

\subsection{Data Analysis}

For data analysis, a relational database management system (RDBMS) was employed. The RDBMS stores data in rows (records) and columns (fields) across multiple tables. The results allow us to pose queries from tables using Structured Query Language (SQL) commands and establish relationships among a large amount of data in a much more accurate, robust and quicker way than manual data analysis. Properly designed relational databases can help determine the level of shared common assumptions (such as vocabulary) among datasets [37]. A database system can be run and managed with various data types (e.g., number, string, ... ). These data may be gathered from different organizations in different forms, and then, a series of queries can be made (Box 4).

Box 4. An example of SQL-based data analysis.

For instance, imagine that many data have been collected from various organizations (e.g., Ministry of Education, Ministry of Health, Municipality) across a province. Then, by using SQL-based data analysis, a specific query can be obtained as outlined below:

Question: Based on multiple prepared tables composed of details of the 30,000 students who have enrolled in 500 schools across 200 districts/villages, find the names of students aged 14 and with a weight of $45 \mathrm{~kg}$ who live in areas with zip codes between 444 and 888 .

Query: "the names of students with age $\underline{14}$ years with the weight more than $\underline{45} \mathrm{~kg}$ who live in zip codes between 444 and $888^{\prime \prime}$

Answer: This analysis maybe ended up with a list of 156 students (out of 30,000!).

In this research, three spreadsheet files were compiled and imported into the SQLbased database management system to obtain queries. Queries are essential mechanisms for users who are consulting database systems [38]. A similar method had been used before to examine the role of newspaper articles in transmitting environmental news to the public [39-41], and searching for thematic areas of research on land degradation and desertification at the global level [42].

Our three spreadsheets were created in three stages:

Stage 1. A spreadsheet with a set of 62 rows and eight columns was created, in which three presumptive specific strategies to deal with wetland odor, as mentioned by students, 
were classified by the author under three groups, including "Prevention", "Identification" and "Restoration" (Table 2). All extracted entries were placed under each strategy, along with their associated approaches. In other words, strategies and approaches were devised after the author screened the answer sheets, but measures were precisely those mentioned by students. Each recommended "Approach" was considered a separate data entry and corresponded to each student (code), meaning that each code could have more than one entry in the corresponding "Approach" column.

Stage 2. A spreadsheet file with 153 rows and four columns was prepared to evaluate the data types mentioned by students. All collated entries were grouped under predefined column subjects after the answer sheets were screened by the author (Table 3). The author defined a column called "data-gathering". However, the data description column was composed of those issues mentioned by students. Each issue suggested by students was considered a separate data entry and corresponded to each student (code), meaning that each code could have more than one entry in the corresponding columns.

Table 2. Summary of students' survey on approaches to identify wetland odor.

\begin{tabular}{|c|c|c|c|c|}
\hline $\begin{array}{l}\text { Strategy (\% of the } \\
\text { Total) }\end{array}$ & Approaches & Measures & $\begin{array}{l}\text { \# of the Total } \\
\text { Responses }(n=62)\end{array}$ & $\%$ of the Total \\
\hline Prevention $(15 \%)$ & Physical and Biological & $\begin{array}{l}\text { Controlling input water, sewage } \\
\text { control, filtering, prevention of } \\
\text { invasive species, sewage treatment }\end{array}$ & 9 & $15 \%$ \\
\hline \multirow[t]{3}{*}{ Identification (55\%) } & Sampling & $\begin{array}{l}\text { Sludge analysis, water sampling, } \\
\text { soil sampling, air sampling, } \\
\text { analysis of pollutants, } \\
\text { microbiological analysis, effluent } \\
\text { sampling }\end{array}$ & 20 & $32.5 \%$ \\
\hline & \multirow{2}{*}{$\begin{array}{l}\text { Social } \\
\text { Site } \\
\text { investigation }\end{array}$} & Questionnaire & 5 & $8 \%$ \\
\hline & & & 9 & $14.5 \%$ \\
\hline Restoration (24\%) & & $\begin{array}{l}\text { Tree planting, rubbish collection, } \\
\text { increasing water flow, wetland } \\
\text { purification using bacteria }\end{array}$ & 15 & $24 \%$ \\
\hline $\begin{array}{l}\text { Answers irrelevant to } \\
\text { the question }(6 \%)\end{array}$ & & $\begin{array}{l}\text { Proclaiming a Protected Area, } \\
\text { public awareness, banning fishing, } \\
\text { reducing industrial development }\end{array}$ & 4 & $6 \%$ \\
\hline
\end{tabular}

Notes: The Strategy and Approaches columns were devised by the author; the Measures column was exactly based on the same wording in the students' answer sheets.

Table 3. Summary of data required to identify wetland odor based on the class survey.

\begin{tabular}{|c|c|c|}
\hline Data (\% of the Total) & Data Gathering & Data Description \\
\hline \multirow{3}{*}{ Water $(71 \%)$} & aqueous solution & $\begin{array}{l}\text { microbiology, BOD, COD, heavy metals, } \mathrm{pH} \text {, turbidity, } \\
\text { ammonia, total phosphorus, total nitrogen, temperature, water } \\
\text { properties, oil, organic carbon, color, sulfide, flora and fauna, } \\
\text { suspended solids, volatile organic acids }\end{array}$ \\
\hline & field observation & $\begin{array}{l}\text { water level, wastewater, wetland features, water inflow, water } \\
\text { outflow, water depth, water storage, sewage, water circulation }\end{array}$ \\
\hline & $\begin{array}{l}\text { hydrology } \\
\text { survey }\end{array}$ & hydrological regime \\
\hline Soil $(8 \%)$ & soil sample & soil properties, soil microbiology \\
\hline Air $(8 \%)$ & $\begin{array}{l}\text { air sample } \\
\text { synoptic station }\end{array}$ & $\begin{array}{l}\text { gaseous components } \\
\text { climatic variables }\end{array}$ \\
\hline Vegetation $(8 \%)$ & plant sample & number of species, diversity of species \\
\hline Humanistic (5\%) & field observation & local people inquiry, surrounding industries \\
\hline
\end{tabular}


Stage 3. A spreadsheet file with 81 rows and three columns was developed to evaluate measures mentioned for removing odors, mentioned by students. All collated entries were grouped under the predefined columns after the author screened the answering sheets (Table 4). One column (Measures) was composed of those issues raised by students. Each issue suggested by students was considered a separate data entry and corresponded to each student (code), meaning that each code could have more than one entry in the corresponding columns.

Table 4. Final solutions and measures recommended by students.

Solution

(\% of the Total)

Physical (50\%) wastewater control, fertilizer control, water replenishment, removal of pollution sources, restoration of environment, sludge removal, revegetation, fecal pollution control, rubbish removal, pesticide control

law enactment, law enforcement, devising sustainable

Legal and

Planning (32\%) development plan, public awareness, monitoring, devising a long-term plan, proclaiming a Protected Area, wetland management, setting the standard eutrophication control, aeration

\section{Results}

\subsection{The First Part of the Question}

What approaches do you suggest to deal with this situation?

Table 2 summarizes strategies, approaches, measures, and the percentage of students' responses to each question.

Almost half of the students (45\%) did not consider the "Identification" strategy or make it their priority to identify the sources of unexpected wetland odor (Table 2). Regardless of such strategy groupings considered in this research, the highest percentage (32.5\%) of approaches for the identification of wetland odor belonged to "sampling", and the least percentage $(8 \%)$ was the "social" aspects (questionnaire). Physical and biological approaches, with a $15 \%$ share, comprised various measures from sewage control to filtering. Only $14.5 \%$ of respondents believed on-site investigation should be their prioritized activity. Finally, $6 \%$ of responses were regarded as unrelated to the question.

Based on data analysis performed for assessing the credibility of measures in removing wetland odor, it was found that the "filtering" measure was equal to "banning fishing" (each was cited once) or "rubbish collection" was equal to "tree planting" or "wetland purification" (each cited four times).

\subsection{Second Part of the Question}

What type of data must be collected for further investigation?

Most data suggested by students were categorized under the "water" data group (71\%) (Table 3). The author grouped "Data gathering" methods for the water section into testing an aqueous solution, field observation, and a hydrology survey. In the student survey, the water data group could comprise various physicochemical and microbiological features and both flora and fauna organisms. According to the student survey, the role of "soil", "air" and "vegetation" data types in identifying wetland odor was the same ( $8 \%$ each). Among the data required, in the eyes of students, "oil" was mentioned only once. The data point "water color" was also only included one time as an important physical feature.

Regarding vegetation, students considered plant "diversity" and "density" as two key pieces of required data. Three students mentioned the requirement of "air samples" to 
detect the odor. The "humanistic" category was the least necessary data required, according to this survey (5\%). Only three students suggested that human-based data be required for collection (one student thought of the importance of making local inquiries). In addition, two students considered climatic data to be critical data for identifying wetland odor.

Based on data analysis to evaluate the data-gathering techniques in removing wetland odor, "aqueous solution" sampling (\# 118) garnered the most frequent mentions, followed by "field observation" (\# 18). The least frequent technique cited by students was "air sampling" (\# 3).

\subsection{Third Part of the Question}

What will be the final solutions in order to eliminate this odor in the long run?

Table 4 summarizes the measures mentioned by students ("Measures" column) that have been categorized by the author ("Solution" column).

Regarding the final solutions, half of the students' suggestions were grouped under "Physical" solutions, followed by "Legal and Planning", "Chemical" and "Biological" solutions (Table 4). A wide range of measures was classified under the final solutions, including diverse topics from law enactment to rubbish removal, to bioremediation. Based on data analysis to evaluate the students' choices as the final measures for removing the wetland odor, "wastewater control" and "water purification" measures were preferred and were at the top of the list, followed by monitoring and "revegetation". The students' least valued measures included "chemical remediation" and "adding oxygen".

Under the "Legal and Planning" solution category, a few students proposed educational, promotional, and legal measures for the local people as long-term solutions. In only one case, "enterprises" were mentioned as being made aware of the situation. In only one case, "punishment" was predicted for illegal behavior causing damage to the wetland. Interestingly, the content of one statement (code 32) emphasized ecosystem services indirectly. These are outlined below:

"Citizens should improve awareness of the importance of wetlands and protect them by more publicity" (code 5)

"Promote education to the local people and enterprises to protect the steady-state" (code 29)

"Educating people in Zone A to know the importance of protecting wetland" (code 17)

"Teach residents how to protect the wetland ... punishing illegal behavior damaging wetland" (code 13)

"Develop the landscape value and ecological value of wetlands so that more people can pay attention to wetland" (code 32)

\section{Discussion}

Water is one of the key renewable sources for nature in the world. In one study, a group of 287 undergraduate students in the US was asked about their thoughts on nature, in which most respondents considered "bodies of water" as one of the vital elements of nature [21]. Like in many developing countries, water resources (e.g., quality, quantity, etc.) are the most severe and challenging issues in the Chinese public's eyes (e.g., [43]). Thus, this research explored this challenging issue through questioning a new engineering generation who will be involved in water-related projects in China in the future. Here, we further elaborate on the findings and compare them with the existing literature.

\subsection{Approaches to Detecting the Wetland Odor}

The first part of the question asked students to enumerate approaches for detecting wetland odor. Students were expected to consider "Identification" strategies as the first action to deal with this unpleasant odor situation as sensed during the field survey. However, statistical results showed different and surprising scenarios. For instance, "site investigation" was an approach grouped under this study's "Identification" strategy. As shown in Table 2, a small portion of respondents listed "site investigation" as an approach 
to finding out the source of the wetland's odor. As the first priority, without knowing the causes and without thinking about the necessity/importance of visiting/surveying the site, students came up with a priori solutions to restore the wetland. $39 \%$ of students did not consider the "Identification" strategy whatsoever to determine the source of unexpected odors. The proportions of these responses were shared between "Restoration" (24\%) and "Prevention" (15\%) strategies. As another finding, most respondents quickly associated bad odor with water and mentioned those measures related to wetland water treatment. Their immediate response was as if the odor would have originated mainly from the water body rather than from areas surrounding the wetland. Sampling was also a highly cited approach as a panacea to detect the sources of odor. Students' suggestions in detecting the odor relied too much on costly in vitro tools and techniques instead of human intuition. Another important finding was that students' confidence in residents living in areas surrounding the wetland when seeking any background or possible causes of odor using questionnaires was poor. A history of complaints, or community odor surveys are listed as potential odor assessment methods [32]. University engineering students are not formally trained to communicate, make inquiries, and negotiate with non-scientists (including local people). That is why many of these students face difficulties when building or interpreting questionnaires for their research projects (author's professional experience).

\subsection{What Types of Data?}

The second part of the question sought the type of data required for assessing unpleasant wetland odor (Table 3). Most students pointed out the "water" of wetland as the main culprit regarding odor and asked for water samples to be analyzed for various physicochemical and microbiological features. In their mind, the immediate cause of odor could be a disturbed or unbalanced distribution/composition of ions, salts, or microbes in the water. The "Vegetation" and "Soils" of wetland were not significant in their eyes in generating unpleasant odors. The "Humanistic" data were also considered insignificant because only a tiny percentage of respondents highlighted such data as useful when assessing anthropogenic factors (e.g., surrounding industries). Again, as illustrated above for the first part of the question, students did not believe the odor source needed clarification from local communities. None of the students mentioned the necessity of relevant published research data to check background evidence and/or a historical trend, as if the problem were only a recent/contemporary event. Only two students enumerated climatic data as being necessary for identifying wetland odor. Most respondents probably did not believe in the wet/drought cycles that affect wetlands from time to time. These hydrological cycles, known as natural drivers of change in wetlands [31], cause the water volume to fluctuate, and impact wetlands either by channeling floodwater and sediments to wetlands (during torrential rainfall) or by reducing oxygen levels (during droughts) (e.g., [44]). Both situations may cause an unpleasant odor in wetlands.

\subsection{Long-Term Solutions for Tackling the Wetland Odor}

The third part of the question asked for long-term solutions. For this part, students finally recognized the importance of "Legal and Planning" solutions (Table 4) and the role of human-based long-term interventions was highlighted by the students. According to the Ramsar Convention, human-induced drivers include "land-use change, climate change, sea-level rise, water abstraction, introduction or removal of species, resource consumption and external inputs (e.g., fertilizers)" ([31], p. 44). It is safe to say that those measures recommended by students, if they were implemented, can tackle most of these issues. However, if those measures attributed to the "Legal and Planning" solution reflect the aspirations of the sustainable development topic, we may conclude that the issue would attract the attention of only one-third of the students in the classroom. Similar to this research, 17 third-year bachelor's degree students between 21 and 24 years old were considered to be assessed for their knowledge of sustainable development goals in the Netherlands [45]. That research also showed uncertainty among students, with 
mixed responses ranging from positive to cautious, to cynical, when they were asked about sustainable development [45].

Comparing the results of Tables 2 and 4, we can establish that, while some measures cited by students (e.g., proclaiming a Protected Area, public awareness) were unrelated to the first question, they were pivotal for removing the wetland odor in the long term. The first question needed a quick response for identifying the odor sources, while the third question challenged students to find solutions in the long run. Thus, most of the students were seemingly unable to distinguish an accurate timeframe for employing each measure in the short and long term. Surprisingly, only two students established a link between the first and third questions. It means that almost none of the students correlated the presumed field survey or laboratory tests (after their first investigation phase) with the final solutions. In contrast to the first part of the question, in which students did not consider the legal or planning aspects of addressing the wetland odor problem, the result of the third question was relatively surprising. Students gave priority to more long-term and sustained solutions.

\subsection{Research Limitations}

The most important limitation was the fact that English was not the students' first language. Moreover, students did not have access to extra information or field visits, as is typical for assessing an actual project. Such logistical shortcomings may have impacted their complete comprehension of the problem and response.

The research presumed that the abovementioned engineering student cohorts represent typical engineering student communities, but we must be careful to acknowledge that these are not fully representative of all environmental engineering students in Asia or around the globe. Although the impact of students' nationalities was not a targeted variable in this research, it has been shown elsewhere that Asian students were the least likely to think about human-made hazards when considering nature [21].

\subsection{Active Learning}

A high level of engagement of students in the classroom, and active teaching strategies, ensure that students can learn more while increasing their lecture attendance, expertise and performance [46-48]. Class engagement reduces students' distractions in the classroom [4]. Furthermore, field survey costs are rising, while unprecedented events such as the COVID19 pandemic may impose restrictions $[49,50]$.

Research with a similar aim, covering 18 undergraduate students in one of the universities in the US, was conducted in which a watercolor painting assignment was incorporated. It showed that such a class activity improved waterfowl identification skills among the students [51]. Elsewhere, a recent finding revealed that in-person field trips could be replaced by virtual field trips for undergraduate level introductory soil science courses to encourage students' learning [52].

Here, we highlighted a classroom activity's role in enhancing active learning among undergraduate students when understanding an environmental challenge. Class simulation activities and assignments are becoming more valid and essential for environmental science studies, particularly wetland science. Moreover, "classroom education cannot address all components required to produce the scientists that will carry wetland science into the future" ([53], p. 583).

\section{Conclusions}

In this research, we evaluated the knowledge and responses of 33 Chinese undergraduate students in tackling wetland odor as one of the most critical environmental issues. As a first-time experiment using SQL in the higher educational context, we evaluated each student's responses within a broader technical and social context. Hopefully, this cross-disciplinary attempt could open up a new horizon for other researchers to compare our findings in other teaching contexts and countries. 
Funding: This research received no external funding.

Institutional Review Board Statement: Not applicable.

Informed Consent Statement: Not applicable.

Conflicts of Interest: The authors declare no conflict of interest.

\section{References}

1. Powell, R.B.; Stern, M.J.; Frensley, B.T.; Moore, D. Identifying and developing crosscutting environmental education outcomes for adolescents in the twenty-first century (EE21). Environ. Educ. Res. 2019. [CrossRef]

2. O'Reilly, C.M.; Gougis, R.D.; Klug, J.L.; Carey, C.C.; Richardson, D.C.; Bader, N.E.; Soule, D.C.; Castendyk, D.; Meixner, T.; Stomberg, J.; et al. Using large data sets for open-ended inquiry in undergraduate science classrooms. Biol. Sci. 2017, 67, 1052-1061. [CrossRef]

3. Sun, R.C.F.; Shek, D.T.L. Student classroom misbehavior: An exploratory study based on teachers' perceptions. Sci. World J. 2012. [CrossRef] [PubMed]

4. Glass, A.L.; Kang, M. Dividing attention in the classroom reduces exam performance. Educ. Psych. 2019, 39, 395-408. [CrossRef]

5. Lambrechts, W.; Van Liedekerke, L.; Van Petegem, P. Higher education for sustainable development in Flanders: Balancing between normative and transformative approaches. Environ. Educ. Res. 2018, 24, 1284-1300. [CrossRef]

6. Abidin, Z.A.Z.; Jacobs, M.H. The applicability of wildlife value orientations scales to a Muslim student sample in Malaysia. Hum. Dimens. Wildl. 2016, 21, 555-566. [CrossRef]

7. Fauville, G.; Strang, C.; Cannady, M.A.; Chen, Y. Development of the International Ocean Literacy Survey: Measuring knowledge across the world. Environ. Educ. Res. 2019, 25, 238-263. [CrossRef]

8. Yanniris, C.; Huang, Y.S. Bibliometric evidence point to loci of empirical knowledge production in environmental education. Cogent Educ. 2018, 5, 1542961. [CrossRef]

9. Fletcher, R. Connection with nature is an oxymoron: A political ecology of "nature-deficit disorder". J. Environ. Educ. 2017, 48, 226-233. [CrossRef]

10. Dunkley, R.A. Learning at eco-attractions: Exploring the bifurcation of nature and culture through experiential environmental education. J. Environ. Educ. 2016, 47, 213-221. [CrossRef]

11. Marchini, S.; Macdonald, D.W. Can school children influence adults' behavior toward jaguars? Evidence of intergenerational learning in education for conservation. Ambio 2020. [CrossRef]

12. Grainger, A. Citizen observatories and the new Earth observation science. Remote Sens. 2017, 9, 153. [CrossRef]

13. Kuthe, A.; Keller, L.; Körfgen, A.; Stötter, H.; Oberrauch, A.; Höferl, K. How many young generations are there?-A typology of teenagers' climate change awareness in Germany and Austria. J. Environ. Educ. 2019, 50, 172-182. [CrossRef]

14. Amiraslani, F.; Caiserman, A. Multi-stakeholder and multi-level interventions to tackle climate change and land degradation: The case of Iran. Sustainability 2018, 10, 2000. [CrossRef]

15. Torbjörnsson, T.; Lundholm, C. Potential conflicts between ownership rights and environmental protection: Swedish undergraduate students' views. Environ. Educ. Res. 2019. [CrossRef]

16. Eaton, E.M.; Day, N.A. Petro-pedagogy: Fossil fuel interests and the obstruction of climate justice in public education. Environ. Educ. Res. 2019. [CrossRef]

17. Castellanos, P.M.A.; Queiruga-Dios, A.; Encinas, A.H.; Acosta, L.C. Environmental education in environmental engineering: Analysis of the situation in Colombia and Latin America. Sustainability 2020, 12, 7239. [CrossRef]

18. Hofverberg, H. Entangled threads and crafted meanings-Students' learning for sustainability in remake activities. Environ. Educ. Res. 2019. [CrossRef]

19. Sjögren, H. More of the same: A critical analysis of the formations of teacher students through education for sustainable development. Environ. Educ. Res. 2019. [CrossRef]

20. Freed, A.; Wong, D. The relationship between university students' environmental identity, decision-Making process, and behavior. J. Sust. Educ. 2019, 20. Available online: http://www.susted.com/wordpress/content/the-relationship-between-universitystudents-environmental-identity-decision-making-process-and-behavior_2019_05/ (accessed on 23 July 2021). [CrossRef]

21. Taylor, D.E. College students and nature: Differing thoughts of fear, danger, disconnection, and loathing. Environ. Manag. 2019, 64, 79-96. [CrossRef] [PubMed]

22. Jorgenson, S.N.; Stephens, J.C.; White, B. Environmental education in transition: A critical review of recent research on climate change and energy education. J. Environ. Educ. 2019, 50, 160-171. [CrossRef]

23. Krasny, M.E.; Kalbacker, L.; Stedman, R.C.; Russ, A. Measuring social capital among youth: Applications in environmental education. Environ. Educ. Res. 2015, 21, 1-23. [CrossRef]

24. O'Flaherty, J.; Liddy, M. The impact of development education and education for sustainable development interventions: A synthesis of the research. Environ. Educ. Res. 2018, 24, 1031-1049. [CrossRef] 
25. Stern, M.J.; Powell, R.B.; Hill, D. Environmental education program evaluation in the new millennium: What do we measure and what have we learned? Environ. Educ. Res. 2014, 20, 581-611. [CrossRef]

26. Tan, E.; So, H. Role of environmental interaction in interdisciplinary thinking: From knowledge resources perspectives. J. Environ. Educ. 2019, 50, 113-130. [CrossRef]

27. Clifford, N.J. The future of Geography: When the whole is less than the sum of its parts. Geoforum 2002, 33, 431-436. [CrossRef]

28. Barnes, T.J. The geographical state: The development of Canadian geography. J. Geogr. High. Educ. 2007, 31, 161-177. [CrossRef]

29. Connell, J. 'I Can't Eat That, It's Purple': A Geography Field Course in Vanuatu and Fiji. Geogr. Res. 2006, 44, 17-27. [CrossRef]

30. Ramsar Convention Secretariat. Wetland Inventory: A Ramsar Framework for Wetland Inventory and Ecological Character Description. Ramsar Handbooks for the Wise Use of Wetlands, 4th ed.; Ramsar Convention Secretariat: Gland, Switzerland, 2010; Volume 15.

31. Ramsar Convention on Wetlands. Global Wetland Outlook: State of the World's Wetlands and Their Services to People; Ramsar Convention Secretariat: Gland, Switzerland, 2018.

32. Ambient Air Quality Assessment. Environment Protection Authority, South Australia. 2016. Available online: www.epa.sa.gov. au/files/12194_ambient_aq_assessment.pdf (accessed on 25 October 2019).

33. Brancher, M.; Piringer, M.; Franco, D.; Filho, P.; De Melo Lisboa, H.; Schauberger, G. Assessing the inter-annual variability of separation distances around odour sources to protect the residents from odour annoyance. J. Environ. Sci. 2019, 79, 11-24. [CrossRef]

34. Odour Methodology Guideline. Department of Environmental Protection Perth, Western Australia. March 2002. Available online: https:/ / www.der.wa.gov.au/.../air/publications/odour-methodology-guidelines.pdf (accessed on 26 October 2019).

35. Hicks, W.; Lamontagne, S. A Guide to Sulfur Gas Emissions from Wetlands and Disposal Basins: Implications for Salinity Management. CSIRO: Australia, 2006. Available online: https: / / publications.csiro.au/rpr/download?pid=procite:6fee71a6-aa5a4900-bdcd-460dd7788adc\&dsid=DS1 (accessed on 16 July 2021).

36. Simpson, G.; Newsome, D. Environmental history of an urban wetland: From degraded colonial resource to nature conservation area. Geo Geogr. Environ. 2017, 4, e00030. [CrossRef]

37. McIntash, A.C.S.; Cushing, J.B.; Nadkarni, N.M.; Zeman, L. Database design for ecologist: Composing core entities with observations. Ecol. Inform. 2007, 2, 224-236. [CrossRef]

38. Rosado, A.; Cardoso, J.M.P. A query processing strategy for conceptual queries based on object-role modeling. In Proceedings of the 4th International Conference on Network and System Security, Melbourne Australia, 1-3 September 2010; pp. 398-403. [CrossRef]

39. Amiraslani, F.; Caiserman, A. From air pollution to airing pollution news: Multi-layer analysis of the representation of environmental news in Iranian newspapers. J. Int. Comm. 2018, 24, 262-282. [CrossRef]

40. Amiraslani, F.; Dragovich, D. Portraying the water crisis in Iranian newspapers: An approach using Structure Query Language (SQL). Water 2021, 13, 838. [CrossRef]

41. Amiraslani, F.; Dragovich, D. Wildlife and Newspaper Reporting in Iran: A Data Analysis Approach. Animals 2021, $11,1487$. [CrossRef] [PubMed]

42. Akhtar-Schuster, M.; Amiraslani, F.; Diaz Morejon, C.F.; Escadafal, R.; Fulajtar, E.; Grainger, A.; Kellner, K.; Khan, S.I.; Perez Pardo, O.; Sauchanka, U.; et al. Designing a new Science-Policy communication mechanism for the UN Convention to Combat Desertification. Environ. Sci. Policy 2016, 63, 122-131. [CrossRef]

43. Aregay, F.A.; Zhao, M.; Li, X.; Xia, X.; Chen, H. The local residents' concerns about environmental issues in Northwest China. Sustainability 2016, 8, 226. [CrossRef]

44. Alho, C.R.; Silva, J.S.V. Effects of severe floods and droughts on wildlife of the Pantanal Wetland (Brazil) -A Review. Animals 2012, 2, 591-610. [CrossRef] [PubMed]

45. Kopnina, H. Teaching Sustainable Development Goals in the Netherlands: A critical approach. Environ. Educ. Res. 2018, 24, 1268-1283. [CrossRef]

46. Deslauriers, L.; McCarty, L.S.; Miller, K.; Callaghan, K.; Kestin, G. Measuring actual learning versus feeling of learning in response to being actively engaged in the classroom. Proc. Natl. Acad. Sci. USA 2019, 116, 19251-19257. [CrossRef]

47. Tharayil, S.; Borrego, M.; Prince, M.; Nguyen, K.A.; Shekhar, P.; Finelli, C.J.; Waters, C. Strategies to mitigate student resistance to active learning. Int. J. STEM Educ. 2018, 5. [CrossRef]

48. Freeman, S.; Eddy, S.L.; McDonough, M.; Smith, M.K.; Okoroafor, N.; Jordt, H.; Wenderoth, M.P. Active learning increases student performance in science, engineering, and mathematics. Proc. Natl. Acad. Sci. USA 2014, 111, 8410-8415. [CrossRef] [PubMed]

49. Nash, C. Improving mentorship and supervision during COVID-19 to reduce graduate student anxiety and depression aided by an online commercial platform narrative research group. Challenges 2021, 12, 11. [CrossRef]

50. Rapanta, C.; Botturi, L.; Goodyear, P.; Guàrdia, L.; Koole, M. Online university teaching during and after the Covid-19 crisis: Refocusing teacher presence and learning activity. Postdigit. Sci. Educ. 2020, 2, 923-945. [CrossRef]

51. Ahlers, A.A. Waterfowl and watercolors: Enhancing undergraduate students' waterfowl identification skills. Nat. Sci. Educ. 2019, 48, 190008. [CrossRef] 
52. Schulze, D.G.; Rahmani, S.R.; Minai, J.O.; Johnston, C.T.; Fulk-Bringman, S.S.; Scott, J.R.; Kong, N.N.; Li, Y.S.; Mashtare, M.L. Virtualizing soil science field trips. Nat. Sci. Educ. 2021, 50,1-13. [CrossRef]

53. Wilcox, D.A. Education and training of future wetland scientists and managers. Wetlands 2008, 28, 578-584. [CrossRef] 